\title{
THE INTELLECTUAL PROPERTY CLAUSE IN CONTEMPORARY TRADEMARK LAW: AN APPRECIATION OF TWO RECENT ESSAYS AND SOME THOUGHTS ABOUT WHY WE OUGHT TO CARE
}

\author{
DAVID L. LANGE*
}

The Congress shall have Power ... to Promote the Progress of Science and the Useful Arts, by securing for limited Times to Authors and Inventors the exclusive right to their respective Writings and Discoveries. ${ }^{1}$

What do we know of the Intellectual Property Clause beyond the fact that it has been part of the Constitution since the inception of the Republic? To whom does it apply: to the states as well as to Congress? And if so, then to private entities exercising state power as well? In what sense, if at all, is the Clause preemptive? And what, if any, are its substantive implications, beyond the ones fairly evident in the text?

That the Clause serves to empower Congress to enact legislation in the complementary fields of copyright and patent law is by now a commonplace. ${ }^{2}$ That it functions in some sense also to constrain Congress in enacting such legislation, through exhortation as well as limitation, seems to be accepted widely as well. ${ }^{3}$ This is so thanks to cases in each field in which the Supreme Court has said so clearly enough to command the acquiescence of all but the most insistently skeptical. ${ }^{4}$

Beyond these two soft areas of general accord, however, the common ground falls away sharply on every hand. There is little certainty as to any aspect of

Copyright $(1996$ by David L. Lange

* Professor of Law, Duke University.

I am deeply grateful to Jeff Smith, a member of the Duke Law School Class of 1998, for invaluable assistance in completing the notes to this article.

1. U.S. CONST. art. I, $\$ 8$, cl. 8.

2. See The Trademark Cases, 100 U.S. 82, 93 (1879); Feist Publications, Inc. v. Rural Tel. Co., 499 U.S. 340,346 (1991).

3. E.g., Jane Ginsburg, No "Sweat?" Copyright and Other Protection of Works of Information After Feist v. Rural Telephone, 92 CoLuM. L. REv. 338, at 369 (1992) ("The Patent and Copyright Clause includes directions and limitations on Congress' authority .....").

4. See Feist, 499 U.S. 340; Graham v. John Deere, 383 U.S. 1 (1966); Mazer v. Stein, 347 U.S. 201 (1954); The Trademark Cases, 100 U.S. 82. But cf. James E. Schatz et al., What's Mine Is Yours? The Dilemma of a Factual Compilation, 17 U. DAYTON L. REV. 423, 437 (1992) ("It seems more likely that the Framers [of the Intellectual Property Clause] intended only to make the broadest policy decisions, allowing that copyrights would be granted to authors, that they would be exclusive, and that they would exist only for limited times. The Framers likely left decisions such as whether the work would be separate from the copyright, whether copyright would exist from creation or publication, and the scope of what was a 'writing' and who was an 'author' to Congress in exercising its power."). 
preemption, either as to Congress or the states. One cannot know, for example, whether Congress may turn to the Commerce Clause in order to enact legislation forbidden by the Intellectual Property Clause. ${ }^{5}$ Nor can one say with assurance whether the states are or are not affected by the Clause. ${ }^{6}$

We know even less about the substantive implications in the Clause. To be sure, the "limited times" provision is taken by most commentators to mean something. ${ }^{7}$ But exactly what that something may be-that is to say, just how limiting the Clause actually is when it comes to copyright or patent terms-is unclear. ${ }^{8}$ For that matter, what an "author" or "inventor" needs to be or to do to satisfy the Clause with respect to "writings" or "discoveries" is clouded with uncertainty. " Whether anything in particular is meant by "promoting the progress of science and the useful arts" is more uncertain still. ${ }^{10}$ And we know nothing at all, yet, of the possibility that other meanings may inhere in the Clause, meanings more shaded and elusive, awaiting the end of a long period of dormancy and an awakening into a new and exigent substantive vitality. ${ }^{11}$

5. Paul Goldstein suggested turning to the Commerce Clause in his Brace Memorial Lecture, which he gave at Columbia in the spring after Feist was decided. See Paul Goldstein, Copyright, 55 LAW \& CONTEMP. PROBS. 79 (Spring 1992). I gave the Brace Lecture the following year-and suggested exactly the contrary! See David Lange, Copyright and the Constitution in the Age of Intellectual Property, 1 J. INTELL. PROP. L. 119 (1993). Jane Ginsburg, meanwhile, thought that perhaps Congress might turn to the Commerce Clause, but only with great care. See Ginsburg, supra note 3, at 369-74; see also David Nimmer, The Death of Copyright, 48 VAND. L. REV. 1385, 1411-12 (1995).

6. See Walter J. Derenberg, Symposium: Product Simulation: A Right or a Wrong?, 64 Colum. L. REV. 1178, 1195 (1964) ("While neither Sears nor Compco involved questions of statutory or common-law copyright, the Court's opinions in both cases unfortunately make certain broad observations with regard to the relationship between federal copyright law and state law of unfair competition that have immediately caused widespread confusion and misapprehension.").

Moreover, this confusion and misapprehension has yet to be resolved. See Howard B. Abrams, Originality and Creativity in Copyright Law, 55 LAw \& CONTEMP. ProBS. 3, 35-39 (Spring 1992) ("The Court has fluctuated over the years in its approach to the issue of preemption of state law protection of intellectual property.").

7. See, e.g., 1 Melville B. Nimmer, Nimmer on COPyright: A TREATISE ON THE LAW OF LITERARY, MUSICAL AND ARTISTIC PROPERTY, AND THE PROTECTION OF IDEAS \$1.05[A][1] (2d ed. 1978).

8. Id.

9. Melville B. Nimmer, The Law of Ideas, 27 S. CAL. L. REV. 119, 140-48 (1954) (discussing the uncertainty and ambiguity of the requirements of concreteness and novelty for the protection of writings and discoveries).

10. Consider, for example, three different interpretations of the phrase: Margaret Chon, Postmodern Progress: Reconsidering the Copyright and Patent Power, 43 DEPAUL L. REV. 97 (1993) ("From the modernist prospective, 'Science and useful arts' can be reduced to the single term knowledge."); Thomas Lizzi, Is Government Ownership of Patents Constitutional, 34 DUQ. L. REV. 299 (1996) ("The useful arts at the time of the writing of the Constitution meant helpful or valuable trades."); Pamela Samuelson, BENSON Revisited: The Case Against Patent Protection for Algorithms and other Computer Program-Related Inventions, 39 EMORY L.J. 1025 (1990) ("Useful arts is understood to be the realm of technological and industrial improvements.").

11. Lange, supra note 5, at 132 ("I would suggest that the Copyright Clause itself may stand at the threshold of a new era of interpretation in which the formalistic distinctions of the past will give way to new, and more harmonious, resolutions of issues we actually confront in intellectual property today-resolutions better suited, in other words, to the new intellectual property millennium-yet resolutions derived finally, once again, under the formal auspices of a new Intellectual Property Clause, a clause newly read as primus inter pares among other clauses within the Constitution."). 
To be sure these issues have not gone unnoticed by commentators, myself among them. ${ }^{12}$ Now two new works, published within a few months of each other, offer welcome additions to the mounting accumulation of literature. One, by Chicago practitioner and Adjunct Professor Malla Pollack, achieves an unusual level of clarity and precision with respect to the threshold issues of preemption at both the state and congressional level. ${ }^{13}$ The other, by Atlanta practitioner and Adjunct Professor Theodore H. Davis, Jr., accepts the public domain as a central issue in any effort to understand the Clause, and on that ground urges the recognition of a wider-than-conventional doctrinal significance in the presence of the text. ${ }^{14}$ Together, these new works serve to bring us still closer to a comprehensive understanding of the Clause.

In this brief essay, I summarize the issues as I see them from the perspective of trademark law. I offer a grateful acknowledgment of the two new works by Pollack and Davis. And I suggest why, in the end, all this sturm und drang about an obscure constitutional clause may matter more urgently than ever as we celebrate the Fiftieth Anniversary of the Lanham Act.

12. I have considered them in several modest essays published in the past half dozen years. See David Lange, Sensing the Constitution in Feist, 17 U. DAYTON. L. REV. 367 (1992); David Lange, Intellectual Property Under the Constitution, 7 DUKE L. MAG. 15 (1989); David Lange, supra note 5. Others have produced more ambitious works. Our agendas have diverged: Some share my concern for the public domain, see Keith Aoki, Authors, Inventors and Trademark Owners: Private Intellectual Property and the Public Domain, Part I, 18 COLUM.-VLA J.L. \& ARTS 1 (1993); some appear to be engaged chiefly by legal process, see Goldstein, supra note 5; and some actually may wish to limit the influence of the Clause, preferring instead to see the reach of intellectual property doctrines extended without unwelcome constitutional interference, see Ginsburg, supra note 3. No matter the perspective or the goal, however, we have all been moved to write, I think, by the suspicion, if not conviction, that the time has finally come when the Clause can no longer escape serious notice.

13. Malla Pollack, Unconstitutional Incontestability? The Intersection of the Intellectual Property and Commerce Clauses of the Constitution: Beyond a Critique of Shakespeare Co. v. Silstar Corp., 18 PUGET SOUND L. REV. 259 (1995). Pollack also offers an intriguing new theory with respect to the constraint posed by the "limited times" provision. Essentially, she suggests that exclusive rights should be measured by the economic life of the work. See id. at 284 . One can be of two minds about whether this is a practical suggestion. In the view of at least some commentators, the economic life of intellectual property is itself largely a matter for hypothesis. See Felix Cohen, Transcendental Nonsense and the Fundamental Approach, 35 ColuM. L. REV. 809 (1935). Cf. Ejan Mackaay, Legal Hybrids: Beyond Property and Monopoly? 94 CoLUM. L. REV. 2630, 2634 n.8 (1994) (quoting George Priest, What Economists Can Tell Lawyers About Intellectual Property, in 8 RESEARCH IN LAW AND ECONOMICS: THE ECONOMICS OF PATENTS AND COPYRIGHTS 19, 21 (John Palmer ed., 1986) ("[I]n the current state of knowledge, economists know almost nothing about the effect on social welfare of the patent system or of other systems of intellectual property.")).

Priest's conclusion correctly sums up the outcome of a debate between two economists, Kenneth Arrow and Harold Demsetz. See Kenneth J. Arrow, Economic Welfare and the Allocation of Resources for Invention, in ECONOMICS OF INFORMATION AND KNOWLEDGE 141 (Donald M. Lamberton ed., 1971); Harold Demetz, Information and Efficiency: Another Viewpoint, in id., at 160.).

14. Theodore H. Davis, Jr., Copying in the Shadow of the Constitution: The Rational Limits of Trade Dress Protection, 80 MINN. L. REV. 595 (1996). 
In The Trademark Cases ${ }^{15}$ decided in 1879 , the Supreme Court suggested that important distinctions separated copyright and patent rights, the traditional subject matter of the Intellectual Property Clause, from the quite separate subject matter of trademark law. So much so, indeed, that the particular requirements of the Clause would not allow Congress to enact trademark legislation under its authority:

The ordinary trade-mark has no necessary relation to invention or discovery. The trade-mark recognized by the common law is generally the growth of a considerable period of use, rather than a sudden invention. It is often the result of accident rather than design, and when under the act of Congress it is sought to establish it by registration, neither originality, invention, discovery, science, nor art is in any way essential to the right conferred by that act. If we should endeavor to classify it under the head of writings of authors, the objections are equally strong. In this, as in regard to inventions, originality is required. And while the word writings may be liberally construed, as it has been, to include original designs for engravings, prints \&c., it is only such as are original, and are founded in the creative powers of the mind. The writings which are to be protected are the fruits of intellectual labor, embodied in the form of books, prints, engravings, and the like. The trade-mark may be, and generally is, the adoption of something already in existence as the distinctive symbol of the party using it. At common law the exclusive right to it grows out of its use, and not its mere adoption. By the act of Congress this exclusive right attaches upon registration. But in neither case does it depend upon novelty, invention, discovery, or any work of the brain. It requires no fancy or imagination, no genius, no laborious thought. It is simply founded on priority of appropriation. We look in vain in the statute for any other qualification or condition. If the symbol, however plain, simple, old, or wellknown, has been first appropriated by the claimant as his distinctive trade-mark, he may by registration secure the right to its exclusive use. While such legislation may be a judicious aid to the common law on the subjects of trade-marks, and may be within the competency of legislatures whose general powers embrace that class of subjects, we are unable to see any such power in the constitutional provision concerning authors and inventors, and their writings and discoveries. ${ }^{16}$

What the Court had to say in The Trademark Cases has contributed enduring insights into the nature of copyrightable works of authorship and patentable inventions under the Intellectual Property Clause. Professor Nimmer offered the Cases as the first (and foundational) entry in his original casebook in copyright. ${ }^{17}$ The Court itself returned to the Cases a few years ago in Feist Publications, Inc. v. Rural Telephone Co. ${ }^{18}$ reiterating in its later opinion the essential point made more than a century before: namely, that the Clause exacts originality and at least some minimal creativity as a condition of the exclusive rights it allows Congress to confer on authors and inventors. ${ }^{19}$

15. 100 U.S. 82 (1879).

16. Id. at 94 (emphasis in original).

17. MELVILle B. NimMer, COPYRIGHT AND OTHER ASPECTS OF LAW PERTAINING TO LITERARY, MUSICAL, AND ARTISTIC WORKS (1st ed. 1971).

18. 499 U.S. 340 (1991).

19. Id. at 345 ("To qualify for copyright protection, a work must be original to the author. Original, as the term is used in copyright, means only that the work was independently created by the 


\title{
But The Trademark Cases had considerably less to say about the singular substantive nature of trademarks themselves under the Constitution:
}

\begin{abstract}
The right to adopt and use a symbol or a device to distinguish the goods or property made or sold by the person whose mark it is, to the exclusion of use by all other persons, has been long recognized by the common law and the chancery courts of England and of this country, and by the statutes of some of the States. It is a property right for the violation of which damages may be recovered in an action at law, and the continued violation of it will be enjoined by a court of equity, with compensation for past infringement. This exclusive right was not created by the act of Congress [at issue in this proceeding], and does not now depend upon it for its enforcement. The whole system of trade-mark property and the civil remedies for its protection existed long anterior to that act, and have remained in full force since its passage. These propositions are so well understood as to require neither the citation of authorities nor an elaborate argument to prove them. ${ }^{20}$
\end{abstract}

Instead, the Court was concerned chiefly with the power of Congress to act at all where trademarks were concerned. ${ }^{21}$ That power was not to be found in the Intellectual Property Clause, for reasons we have seen, and not to be found in the Commerce Clause either, for that matter-at least not in The Trademark Cases. Speaking to this latter possibility, the Court said the Act seemed clearly to contemplate a broader class of subject matter, and subject matter benefiting more persons, than the Commerce Clause would allow in the circumstances, given its limited application to "commerce with foreign nations, commerce among the states, and commerce with the Indian tribes."22

author, and that it possesses at least some minimal degree of creativity."), 347 ("The originality requirement articulated in the Trademark Cases and Burrow Giles remains the touchstone of copyright protection today."). Of course Feist was a copyright case, and some would think it limited in its application merely to authors; but Justice O'Connor's clear reliance on The Trademark Cases convinces me that what she said in Feist applies to inventors as well; so I shall think, at least, until persuaded otherwise.

20. The Trademark Cases, 100 U.S. at 92.

21. Id. at 93 .

As the property in trade-marks and the right to their exclusive use rest on the laws of the States, and, like the great body of the rights of person and of property, depend on them for security and protection, the power of Congress to legislate on the subject, to establish the conditions on which these rights shall be enjoyed and exercised, the period of their duration, and the legal remedies for their enforcement, if such power exist at all, must be found in the Constitution of the United States, which is the source of all the powers that Congress can Id. lawfully exercise.

\section{Id. at $97-98$.}

Here [in the Act in question] is no requirement that such persons shall be engaged in the kind of commerce which Congress is authorized to regulate. It is a general declaration that anybody in the United States, and anybody in any other country which permits us to do the like, may, by registering a trade-mark, have it fully protected. So, while the person registering is required to furnish 'a statement of the class of merchandise, and the particular description of the goods comprised in such class, which the trade-mark has been or is intended to be appropriated,' there is no hint that the goods are to be transported from one State to another, or between the United States and foreign countries. Sect. 4939 of the July 8, 1970 act entitled "An Act to Revise, Consolidate, and Amend the Statute Relating to Patents and Copyrights" is intended to impose some restriction upon the Commissioner of Patents in the matter of registration, but no limitation is suggested in regard to persons or property engaged in the different classes of commerce mentioned in the Constitution. The remedies provided by the act when the right of the owner of the registered trade-mark is infringed, are not confined to 
To be sure, the question of congressional power to act under the Constitution was not a small one in its day. The Commerce Clause had yet to come into its own; if the Intellectual Property Clause was unavailable, then congressional authority to act in a plenary way to secure trademarks was anything but clear. And indeed, as every student of trademark law knows, Congress actually did not succeed in enacting comprehensive legislation of a satisfactory sort until the passage of the Lanham Act in $1946 .^{23}$

By that time, decisions in Depression-era cases elaborating congressional authority under the Commerce Clause had obviated the impediments raised in the previous century. ${ }^{24}$ In the half-century since, trademark law and its close relative, unfair competition, have advanced all but unchallenged by any constitutional constraint whatsoever. It is indeed this very evolution-well worth celebrating in so many ways-that has led to this Symposium on the Lanham Act.

Meanwhile, however, the important substantive constitutional delineations among copyright, patent law, and trademarks remain essentially where the Court left them in 1879: The Court has spoken to these issues infrequently, and always from the perspective of the Intellectual Property Clause rather than the Commerce Clause. One cannot know with any degree of certainty, merely from reading the Court's opinions, whether rights equivalent to copyright and patent also may be grounded in the Commerce Clause. Nor, for that matter, has the Court explicitly considered the possibility that some trademarks may well reflect

the case of a trade-mark used in foreign or inter-state commerce.

It is therefore manifest that no such distinction is found in the act, but that its broad purpose was to establish a universal system of trade-mark registration, for the benefit of all who had already used a trade-mark, or who wished to adopt one in the future, without regard to the character of the trade to which it was to be applied or the residence of the owner, with the solitary exception that those who resided in foreign countries which extended no such Id. privileges to us were excluded from them here.

23. Act of July 5, 1946, 60 Stat. 427 (codified as amended at 15 U.S.C. $\$$ 1051-1127 (1994)); see Miles J. Alexander \& Michael K. Heilbronner, Dilution Under Section 43(c) of the Lanham Act, 59 LAW \& CONTEMP. PROBS. 93 (Spring 1996). In 1946, in the legislative history of the Lanham Act, Congress recognized the need for national and uniform protection of trademarks greater than that provided under existing federal trademark laws:

"[T]rade is no longer local, but is national. Marks used in interstate commerce are properly the subject of federal regulation. It would seem as if national legislation along national lines securing to the owners of trademarks in interstate commerce definite rights should be enacted and should be enacted now."

Id. at 98 (quoting S. REP. No. $79-1333$ (1946), reprinted in 1946 U.S.C.C.A.N. 1274, 1277),

24. See $1 \mathrm{~J}$. ThOMAS MCCARTHY, TRADEMARKS AND UNFAIR COMPETITION \$6.01[2], at 6-3 (3d ed. 1993) ("In 1879, the United States Supreme Court rejected the argument that Congress had the power under [the Intellectual Property] Clause of the Constitution to regulate or register trademarks."); see also Pollack, supra note 13, at 270 ("In 1879, the [Commerce] clause could not ground trademark legislation that did not expressly exclude marks used in commerce between citizens of the same state. By 1942, it covered regulation of grain intended, not for sale, but for consumption on the farm where it was produced."). Still, even as Pollack acknowledges the expansion of the Commerce Clause, she points out that "Congress may not ... transcend specific limitations on its exercise of the commerce power that are imposed by other provisions of the Constitution." Pollack, supra note 13, at 270 (citing EEOC v. Wyoming 460 U.S. 226, 248 (1983) (Stevens, J. dissenting)). 
attributes of authorship or invention in sufficient measure to justify or require protecting them under the Intellectual Property Clause after all. ${ }^{25}$

But why should we care? Why, that is, should we suppose that an increased role for the Intellectual Property Clause is important? Certainly the doctrinal law itself has not remained static; far from it.

The passage of time, and with it the accretion of subsequent cases, new legislation, and regulations as well as commentary sacred and profane, not to mention accords tacit and explicit alike, have brought a measure of resolution to these issues at certain levels of doctrinal understanding. Certainly, no one doubts today that copyrightable subject matter may have additional protection under the Lanham Act when the separate requirements of that Act are met; ${ }^{26}$ the same apparently is true of patentable subject matter. ${ }^{27}$ Trademarks, meanwhile, may be protected by copyright when they meet the requirements of

25. The Supreme Court's post-Trade-Mark Cases opinions have hardly been a beacon of light to the fields of intellectual property and unfair competition. The decisions have both expanded and limited the power and application of the Intellectual Property Clause, and intellectual property rights in general. See Burrow-Giles Lithographic Co. v. Sarony, 111 U.S. 53 (1884) (holding that a photograph satisfies the requirements of originality to secure a copyright); Bleistein v. Donaldson Lithographing Co., 188 U.S. 239 (1903) (giving copyright protection to reduced forms of chromo lithographs); Sears, Roebuck \& Co. v. Stiffel, 376 U.S. 225 (1964); Compco Corp. v. Day-Brite Lighting, Inc., 376 U.S. 234 (1964); Brulotte v. Thys, Co., 379 U.S. 29 (1964); Lear, Inc. v. Adkins, 395 U.S. 653 (1969) (using the Intellectual Property Clause to directly preempt any state protection of intellectual property that interfered with federal goals and policies).

Soon after the decision in Lear, however, the Court handed down decisions in a series of cases that seemed to place distinct limitations upon congressional powers under the intellectual property clause. See Davis, supra note 14, at 614 ("The court began to back off Compco's theory of the Intellectual Property Clause as an affirmative bar to state protection of intellectual property rights in Goldstein v. California."). In Goldstein, the Court concluded that "the clause of the Constitution granting to Congress the power to issue copyrights does not provide that such power shall vest exclusively in the federal government. Nor does the Constitution expressly provide that such power shall not be exercised by the states." Goldstein v. California, 412 U.S. 546, 553 (1973). The Court reaffirmed this holding in Kewanee Oil Corp. v. Bicron Corp., 416 U.S. 470 (1974), and Aronson v. Quick Point Pencil Co., 440 U.S. 257 (1979).

Also, "[m] ost recently, in Bonito Boats, Inc. v. Thunder Craft Boats, Inc., [489 U.S. 141 (1989),] the court appeared to waver between a preemption analysis based solely on the relationship between state law and federal statute, and a broader preemption analysis derived from the Patent-Copyright Clause." Ginsburg, supra note 3, at 363.

What is interesting to note in the line of cases concerning the extent protection can be granted to intellectual property is that none of them consider the effect that the Commerce Clause may have upon such protection. This is noticeably absent, especially considering the effect that state protection of intellectual property can have upon interstate commerce. Moreover, trademark protection, which has traditionally been protected under the Commerce Clause, may well be protectable under the Intellectual Property Clause. See David Klein, The Ever-Expanding Section 43(a): Will the Bubble Burst?, 2 U. BALT. INTELL. PROP. J. 65 (1993) ("The trade dress protection afforded by section 43(a) not only overlaps the intellectual property area of design patents, but also overlaps copyrights as well.").

26. See 1 MCCARTHY, supra note 24, \&6.04[2], at 6-26 to -27 ("For example, a picture of a person or character is copyrightable as a pictorial work and may also be used as a mark to identify the source of goods and services. ... Where there is an overlap between trademark and copyright protection, expiration of the copyright does not bar a claim for trademark or trade dress.").

27. Id. ("Dual protection from both design patent and trademark law may exist where it is alleged that the configuration or shape of the container or article serves to identify and distinguish the source of the goods-that is, acts as a trademark or trade dress."). 
authorship and originality. ${ }^{28}$ Whether the subject matter of trademarks also may be patentable is less clear. But the Federal Circuit is currently considering a case in which the proprietors of trade dress are claiming the rights of a patentee. Assuming novelty, nonobviousness, and utility, nothing seems clearly to stand in the way of such a result. ${ }^{29}$

We have learned, in short, to accommodate complexities in the field of intellectual property that would have confounded the Court that decided The Trademark Cases a little more than a century ago. And we have done so, as I say, largely unguided and unconstrained by the constitution. This is indeed why the Intellectual Property Clause matters now as it has not in the past.

In the view of many observers, myself among them, we have learned to be a bit too accommodating. ${ }^{30}$ The complexities in the interplay among our contemporary doctrines now allow a degree of slippage that is unwise twice over.

We are unwise, first, in the confusion we have sown among doctrines once admirably self-contained. For what is implicit in The Trademark Cases is that there is a fundamental difference between copyright and patent rights, on the one hand, and trademarks on the other. Indeed, at the time, there was.

Trademarks then served almost exclusively to prevent confusion in the marketplace among branded goods; and though the right might be seen as in the nature of property (the Court itself seemed so to see it in that case), ${ }^{31}$ still the principal justification for the trademark proprietor's interest was in turn the public's interest in avoiding confusion, deception, and the like. The trademark proprietor stood in the public's shoes, as it were; the principal theories of the day sounded in fraud, deceit, and mistake; the concept of "passing off" was at the center of the field. ${ }^{32}$ Not until after the First World War did we encounter

28. 1 NIMMER, supra note 7, $\$ 2.08[G][3]$ ("However, although a clearly fanciful label will undoubtedly be found sufficiently original, there is some tendency to require a somewhat greater degree of originality in labels than in other works."). The treatise shows Bleistein v. Donaldson Lithographing Co., 188 U.S. 239 (1903), as the leading case for showing that the doctrine of originality must be satisfied for a trademark to be copyrightable. Id.

29. See Davis, supra note 14, at 622 ("Although it may be true that 'it is the provence of patent law, not trademark law, to encourage invention by granting inventors a monopoly over new product designs or functions for a limited time,' it is equally true that, as a matter of statutory law, there is nothing to prevent Congress from altering this balance.").

30. The literature to this effect is vast and rich. Among even the most recent works true treasures abound. See, e.g., Aoki, supra note 12; Melissa R. Gleiberman, From Fast Cars to Fast Food: Overbroad Protection of Product Trade Dress Under Section 43(a) of the Lanham Act, 45 STAN. L. REV. 2037 (1993); Malla Pollack, Your Image is My Image: When Advertising Dedicates Trademarks to the Public Domain-With an Example From the Trademark Counterfeiting Act of 1984, 14 CARDOZO L. REV. 1391 (1993).

31. The Trademark Cases, 100 U.S. 82, 92 (1879) ("The right to adopt and use a symbol or a device to distinguish the goods or property made or sold by the person whose mark it is . . . is a property right for the violation of which damages may be recovered in an action at law.").

32. Compare Daniel M. McClure, Trademarks and Unfair Competition: A Critical History of Legal Thought, 69 TRADEMARK REP. 305, 314-15 (1979):

The development of trademark law in America paralleled that of English law. It developed as an offshoot of the tort of fraud and deceit, and was called 'passing off.'... Although protection of the public from deception and confusion was recognized as one basis 
a serious interest in the very different theory of "misappropriation,"33 and even then we were some years from a coherent statement of what Professor Schecter was to call "the rational basis of trademarks." 34

Schecter's insight-namely, that the trademark proprietor's interest lies mainly in recouping and then protecting the investment made in creating and promoting the mark $\mathrm{k}^{35}$-has come to dominate the thinking in a field in which, increasingly, the rhetoric of "free riding" or "reaping where one has not sown" is a central concern. ${ }^{36}$ Within limits, I have no quarrel with this discourse. It is rational to wish to protect an investment; and while Professor Cohen has observed correctly that the resulting interest is neither a natural nor a moral right, ${ }^{37}$ still there is both practical sense and surely some ethical entitlement in the idea that trademarks are the property of proprietors for reasons that do not

for trademark suits, the dominant rationale for relief in such cases was 'the promotion of honesty and fair dealings, because no one has a right to use his own goods as the goods of another.' . . . The early development of trademark law in America was thus based firmly on notions of morality, focusing on the fraudulent activity of the defendant.

Id.

33. The rationale for the misappropriation doctrine, as set forth in the Third Restatement of Unfair Competition, is that "[p]rotection against the misappropriation of intangible trade values insures an incentive to invest in the creation of intangible assets and prevents the potential unjust enrichment that may result from the appropriation of an investment made by another." RESTATEMENT (THIRD) OF UNFAIR COMPETITION $\$ 38 \mathrm{cmt}$. b (1995) [hereinafter RESTATEMENT].

See also International News Service v. Associated Press, 248 U.S. 215 (1918) (the first case recognizing the common tort of misappropriation); McClure, supra note 32, at 324-25 ("The high water mark of formalist conceptualism in trademark-unfair competition law occurred in 1918 with the holding in [INS v. AP]. The property conception was analogized to a case far removed from 'property as land' or even 'property as trademark.' The plaintiff, Associated Press, was accorded property rights in the fruit of its labor.").

Finally, it is important to note that the Restatement now tries to cut back on misappropriation-based theories, limiting them to only two: right of publicity and trade secrets. See RESTATEMENT, supra, § 38 cmt. b ("The rule stated in this section limits common law tort liability for appropriations of intangible trade values to cases involving an appropriation of trade secrets, an appropriation of the commercial value of another's identity, or an appropriation of a work of authorship that is not fixed in a tangible medium of expression ....").

34. Frank I. Schecter, The Rational Basis of Trademark Protection, 40 HARV. L. REV. 813 (1927).

35. Id. at 830-31 ("From the necessities of modern trademark protection . . the following principles emerge: (1) that the value of the modern trademark lies in its selling power; (2) that this selling power depends for its psychological hold upon the public, not merely upon the merit of the goods upon which it is used, but equally upon its own uniqueness and singularity; (3) that such uniqueness or singularity is vitiated or impaired by its use upon either related or non-related goods; and (4) that the degree of its protection depends in turn upon the extent to which, through the efforts or ingenuity of its owner, it is actually unique and different from other marks.").

What Schecter did in essence was to bring the trademark proprietor's interest front and center, by emphasizing the need to recoup investments made in developing marks that are unique and singular. The "efforts and ingenuity" of the makers of the trademark was thus proposed as a separate, additional, and ultimately more important basis for protecting trademarks than the public's right to avoid being confused.

36. See McClure, supra note 32, at 325 (quoting International News Service, 248 U.S. at 239-40) ("The Court (in INS $v$. AP) recognized a 'quasi property' right in the news. The court stated that by appropriating material acquired by AP as a result of AP's 'expenditure of labor, skill, and money,' INS 'is endeavoring to reap where it has not sown, and . . . is appropriating to itself the harvest of those who have sown." ).

37. Cohen, supra note 13. 
depend alone, or perhaps even primarily, on the public's separate interest in freedom from confusion.

But we have glutted ourselves on the notion; Schecter's arguments have been carried far from the thesis he offered in 1923. I have elaborated this point before: We repeatedly recognize trademark interests too trivial to deserve protection; and we protect trademark interests as property for no better reason than that, having marked the interest as its own, the would-be proprietor then has asked us so to do. ${ }^{38}$

The result is one I think Schecter himself would have denounced: We no longer know where the rational limits of trademarks lie. My colleague Paul Carrington likens the law to Mark Twain's River, rolling on forever and charting new meanders as it flows. ${ }^{39}$ It is a pretty metaphor. In the field of trademarks and unfair competition, though, it often seems that the river is over its banks; the boundaries among doctrines are no longer clear. ${ }^{40}$ And we are unwise, I would insist again, in allowing that to happen-unwise for perfectly straightforward doctrinal reasons wholly internal to the field. Lawyers cannot help clients whom they cannot counsel, and lawyers cannot counsel clients effectively about law they cannot sensibly predict or explain or defend.

We are unwise, moreover, in the separate and additional degree to which we have allowed intellectual property doctrines to encroach upon the public domain. This is not a new problem in trademark law. The protean nature of trademark doctrines has been apparent for the better part of two decades. But one now senses a kind of critical mass as a new millennium approaches and new technologies converge with subject matters once the province of separate doctrines. ${ }^{41}$

In this respect, trademark law joins the rest of the intellectual property field. What has always been at best an uneasy truce between intellectual property and freedom of expression ${ }^{42}$ is in danger of being subsumed by the sheer velocity and mass of the former and the inherent resiliency of the latter. Professors Gaines and Coombe, Aoki and Boyle, and many others have all written eloquently of these increasing threats. ${ }^{43}$ Even judges, too many of whom have

38. David Lange, Recognizing the Public Domain, 44 LAW \& COMTEMP. PROBS. 147 (Autumn 1981).

39. Paul D. Carrington, Of Law and the River, 35 J. LEGAL EDUC. 1 (1985).

40. Cf. J.H. Reichman, Past and Current Trends in the Evolution of Design Protection Law-A Comment, 4 FORdHAM INTELL. PROP., MEDIA \& ENT. L.J. 387, 397 (1993) ("As Stephan Ladas pointed out, trademark and unfair competition laws lack the limitations and safeguards that positive intellectual property laws establish in order to balance the long-term public interest against short-term restraints on trade.").

41. See Aoki, supra note 12.

42. See Robert C. Denicola, Copyright and Free Speech: Constitutional Limitations on the Protection of Expression, 67 CALIF. L. REV. 283 (1979); Paul Goldstein, Copyright and the First Amendment, 70 Colum. L. Rev. 983 (1970); Melville B. Nimmer, Does Copyright Abridge the First Amendment Guarantees to Freedom of Speech and Press?, 17 UCLA L. REV. 1180 (1970).

43. See Jane M. Gaines, ConTested Culture: The IMAGe tHE Voice, AND tHe LAw (1991); Rosemary J. Coombe, Objects of Property and Subjects of Politics: Intellectual Property Law and Democratic Dialogue, 69 TEX. L. REV. 1853 (1991); Aoki, supra note 12; JAMES BoYLe, ShAMANS, 
been lamentably silent in the past, are beginning to acknowledge the importance of recognizing the public domain. ${ }^{44}$

That recognition, such as it is, comes none too soon. Beyond unwisdom, the current course we have charted is, I believe, pragmatically indefensible as well. For it is the truce itself that is endangered; with excesses abounding on every han $\mathrm{d}^{45}$ and the first amendment clearly waiting in the wings, ${ }^{46}$ the outcome of the conflict is less clear than appeared evident at one time.

I have supposed for almost twenty years that increased concern for the sanctity of doctrines, including their limits and constraints, is necessary because otherwise (considerably to oversimplify the proposition) the rapid growth of intellectual property in our time would damage or destroy the public domain, thereby eventually impeding our ability to inherit and bequeath the culture. ${ }^{47}$ Today I am less certain whether that is indeed where the main danger lies.

It is, I now believe, an open question whether intellectual property as we have known it can survive into the next millennium. Given the nature of the new technologies, the balance of power between the public domain and intellectual property may well have shifted; the longer term advantage may now actually lie with the public domain. ${ }^{48}$

This is a thesis still unresolved in my own mind. But others appear to believe that this may be $\mathrm{so}^{49}$ and if they are correct, their insight speaks to a different urgency than $I$ have seen myself in calling for increased clarification among doctrines. My concern has been for the public domain; the alternative

SOFTWARE \& SPLEENS: LAW AND THE CONSTRUCTION OF THE INFORMATION SOCIETY (1996); Pollack, supra, note 30.

44. See White v. Samsung Elecs. Am., Inc., 989 F.2d 1512 (9th Cir. 1993) (Kozinski, J., dissenting).

45. Lunacy of ten appears to control the asylum, unchecked by common sense. As if the Ninth Circuit's ruling in the Vanna White case were not bad enough, some lawyers are now suggesting that novel sports plays ought to be the province of patent law-in consequence of which, presumably, inventive players like Dick Fosbury (the "Fosbury Flop") or Kareem Abdul-Jabbar (the "sky hook") might collect royalties in the event of (or even forbid!) the use of such plays by others. See Hal Block, Patented Moves, Durham (N.C.) Herald-Sun, June 17, 1996, at C2. Joseph Welsh's celebrated rhetorical cri de couer from a confrontation central to another age rings in my head as I draft this note: "Have we then no decency, no decency at last?"

46. See, e.g., Wendy J. Gordon, $A$ Property Right in Self-Expression: Equality and Individualism in the Natural Law of Intellectual Property, 102 YALE L.J. 1533 (1993); Dorean M. Koenigfn, Joe Camel and the First Amendment: The Dark Side of Copyrighted and Trademark-Protected Icons, 11 T.M. COOLEY L. REV. 803 (1994); Lange, supra note 5; Alfred Yen, A First Amendment Perspective on the Idea-Expression Dichotomy and Copyright in a Work's "Total Concept and Feel," 38 EMORY L.J. 393 (1989); Pamela Samuelson, Reviving Zacchini: Analyzing First Amendment Defenses in the Right of Publicity and Copyright Cases, 57 TUL. L. REV. 836 (1983). See also William W. Van Alstyne, Remembering Melville Nimmer: Some Cautionary Notes on Commercial Speech, 42 UCLA L. REV. 1635 (1996).

47. See Lange, supra note 38.

48. See David Lange, At Play in the Fields of the Word: Copyright and the Construction of Authorship in the Post-Literate Millennium, 55 LAW \& CONTEMP. PROBS. 139 (Spring 1992).

49. See James Boyle, $A$ Theory of Law and Information: Copyright, Spleens, Blackmail, and Insider Trading, 80 CALIF. L. REV. 1413 (1992); Gordon, supra note 46; Michael Madow, Private Ownership of Public Image: Popular Culture and Publicity Rights, 81 CaLIf. L. REv. 125 (1993). Cf. Jessica Litman, Copyright Legislation and Technological Change, 68 OR. L. REV. 275 (1989). 
perspective actually suggests that intellectual property itself may be threatened. ${ }^{50}$

The argument runs this way: Intellectual property doctrines have gained ascendance slowly, over a long period of time, during which the press has lent authority to certain forms of work. ${ }^{51}$ The public has benefitted in the best of circumstances, albeit indirectly, in that the works celebrated and sanctified by intellectual property eventually also have enriched the public domain.

In truth, however, the public's enthusiasm for, indeed, the very question of the public's acceptance of intellectual property has never been put directly to the test. Only in the past few decades have individuals begun to have intimate daily contact with the main engines of exploitation in this field, and only more recently still have we gained a nascent understanding of our own potential ability to produce these works ourselves. ${ }^{52}$

Whether in the end we accept the main tenets of intellectual property depends, then, to a considerable extent on how we score the answers to two questions: first, whether we can comprehend the doctrines well enough to obey them, and, second, whether we think them sensible and fair. If on either ground we are disappointed, then the intellectual property enterprise will simply fail or be subsumed. ${ }^{53}$ In these circumstances, no one given to a sympathetic appreciation of the field can continue sensibly to defend the doctrinal excesses of the past twenty years.

It seems especially appropriate, then, to pay renewed attention to the role the Clause could play in the governance of intellectual property law in general and trademark law in particular. Professors Pollack and Davis, who clearly have some of these concerns in mind themselves, have responded with articles fully deserving of our attention.

II

I have suggested that there are three questions in need of answers: (1) Can Congress turn to the Commerce Clause to circumvent limits or restrictions in

50. See John Perry Barlow, The Economy of Ideas, WIRED, Nov. 1994.

51. See Elizabeth Eisenstein, The Printing Press As AN Agent of Change 229 (1979) ("Scribal culture could not sustain the patenting of inventions or the copyrighting of literary compositions. It worked against the concept of intellectual property rights. . . With the typographical fixity and attribution made possible by printing, authorship became a matter of personal responsibility, and respect for 'wisdom of the ages' correspondingly declined.").

Eisenstein's work lends itself to a further argument along the Austrian economic lines that Tom Palmer makes in his 1989 piece on the law and economics approach to intellectual property. See Tom G. Palmer, Intellectual Property: A Non-Posnerian Law and Economics Approach, 12 HAMLINE L. REV. 261,273 (1989) ("Authorship and invention, the very acts to be rewarded by intellectual property law, may not be timeless concepts plucked from Heaven but may emerge in conjunction with-and be inextricably intertwined with-the technology that makes them possible.").

52. I intend my observations here to seem familiar to anyone who has a grounding in the field. For a useful collection of citations to relevant literature, see Litman, supra note 49, at 277 .

53. Professor Raymond Nimmer made essentially this same point at a conference organized by Professor David Rice at Rutgers earlier this year. 
the Intellectual Property Clause? (2) Are the states free to act even when Congress itself cannot? (3) Are there substantive limitations inherent in the Clause that go beyond the text?

\section{A. The Commerce Clause: A Refuge?}

Pollack and Davis agree that the Commerce Clause cannot supplant the Intellectual Property Clause so as to enable legislation under the former plainly forbidden by the latter. Their reasons for thinking so do not entirely correspond, however.

For Pollack the answer turns on an assessment of equivalency: The Commerce Clause cannot serve as a refuge when its use results in legislation plainly equivalent, in important respects, to legislation also plainly forbidden by the Intellectual Property Clause. "Under certain circumstances," she writes, "other [c]onstitutional provisions may act as limits upon the Commerce Clause: These include the Bankruptcy Clause, and the Fifth, Sixth, Tenth, and TwentyFirst Amendments. These various provisions have kept Congress from utilizing the Commerce Clause as a means to avoid the provisions' requirements." 54 "Seemingly," she concludes, "if a separate constitutional phrase (1) includes a limit by negative implication, and (2) this limit has not been interpreted out of the clause, Congress cannot bypass the limit through the Commerce Clause." Under her analysis the "limited times" provision of the clause amounts to one such limiting implication. ${ }^{55}$

Equivalency, in Pollack's view, is a question of substance, not form. Rights and remedies presumably count; mere doctrinal terms do not:

The Intellectual Property Clause, containing the Copyright and Patent Clauses, mentions neither the word "patent" nor the word "copyright." It allows Congress to grant "exclusive rights" in "writings" and "discoveries" to their "authors" and "inventors" in order to "promote science and the useful arts." At the time the Constitution was written, England had legal rights, well known to the Framers, called patents and copyrights. The only logical conclusion from the Framers' choice not to use these words is that they did not want to tie the Clause to the technical meaning of "patent" and "copyright." The non-use of "patent" and "copyright" by the Framers means that similarity to statutory copyrights and patents is not the test for the constitutionality of Commerce Clause-based rights in intellectual property. Instead, suspect provisions must be compared to "exclusive rights" over "writings and discoveries" given to "authors and inventors" for "limited times" in order to "promote the progress of science and the useful arts." 56

This is a promising approach in theory, perhaps; in practice one must wonder whether it is likely to lead to useful results in the near term. The problem is simply that the relevant language in the Clause means nothing as yet. Pollack, concentrating as she does on the "limited times" provision, is able to tease meaning from that phrase, but not easily and, more to the point, not in ways

54. Pollack, supra note 13 , at 270.

55. See id. at 275-87.

56. Id. at $290-91$. 
that are certain to command wide assent. ${ }^{57}$ Equivalency is surely a necessary approach to the problem, but this version of it is in no sense easy.

In contrast, Professor Jane Ginsburg, writing in the aftermath of the Court's landmark decision in Feist Publications v. Rural Telephone Co. ${ }^{58}$ also suggested an equivalency test to the same end. ${ }^{59}$ But Ginsburg's test was keyed to the already sanctioned conceptualizations in copyright itself and seemed therefore somewhat more likely to be accessible. ${ }^{60}$

For Davis, meanwhile, equivalency also is the test by which Commerce Clause legislation must be measured against Intellectual Property Clause limitations. ${ }^{61}$ Unlike Pollack, however, and with an enthusiasm Ginsburg does not share, Davis embraces what he sees as Feist's broader, deeper teaching-namely, that the public domain implies a "right to copy," which derives from Sears-Compco and subsequent cases and is itself constitutionally protected against encroachment. ${ }^{62}$

57. See id. at 286 ("Other readings are possible. For instance, the change to 'limited times' may have intended to allow renewable terms .... . Perhaps the best reading is that the change was meant to clarify that the limited time granted inventors does not have to be of the same length as the limited times allowed authors. However, all these suggestions are guesses unbacked by historical evidence." (emphasis added)).

58. 499 U.S. 340 (1991).

59. See Ginsburg, supra note 3, at 369-74.

Assuming that the more specific clause does limit the more general one, Congress does not have the power to override Patent-Copyright Clause limitations by creating under the Commerce Clause a form of protection of consecutive information coextensive with copyright protection .... The federal trademarks law affords protection not against copying per se, but against falsehoods in the marketplace. As a result, the protection afforded under the Lanham Act is not substantively equivalent to copyright or patent protection. One may therefore contend that the Commerce-Clause-dependent Lanham Act does not run afoul of the PatentCopyright Clause limitations, for the federal trademarks law governs conduct different from Id. that at issue in patent and copyright laws.

60. Pollack's departure from Ginsburg on this point is deliberate:

I agree with Jane Ginsburg's conclusion that a statute under the Commerce Clause would be constitutional if "the protective law departs in significant ways from the copyright model," provided it also allowed the free-riding on "sweat works" labeled a constitutional policy in Feist .... I disagree only by clarifying that the differences must be judged against the constitutional mandate of the Intellectual Property Clause, [and Authors' exclusive rights,] not the Copyright Statute Congress chose to enact.

Pollack, supra note 13, at 291 n.163.

61. Davis, supra note 14 , at $640-41$.

62. Davis reasons that

[e]ven if perpetual protection for functional configurations is a proper vehicle for stimulating commerce, Congress cannot override constitutional limitations on its own authority merely by invoking the Commerce Clause. On the contrary, it is apparent that 'Congress has plenary authority in all areas in which it has substantive legislative jurisdiction so long as the exercise of that authority does not offend some other constitutional restriction.

Indeed, in the wake of Feist's linkage of the right to copy to the Constitution itself, even critics of Feist have questioned congressional authority to override the decision through legislation promulgated under the Commerce Clause. Although Congress may indeed create "other federal statutory protection" outside the restrictions of the Intellectual Property Clause, efforts to evade the Clause's limits are valid only if they create qualitatively different protection. 
Ultimately, then, Congress is limited under the constitution by certain substantive prerogatives located in the public domain where they reside as natural rights antecedent to the rights of those intellectual property proprietors whom the Clause envisions. The public domain may be set aside only when the prerequisites of the Clause have been met in every particular. "End runs," in

Id. (emphasis added). Under either approach, what Pollack and Davis have in mind, when they discuss equivalency, is the question raised in cases involving functionality in trade dress-cases like Shakespeare Co. v. Silstar Corp., a 1993 Fourth Circuit decision, which clearly prompted each of them to write. See 802 F. Supp. 1386 (D.S.C. 1992), rev'd, 9 F.3d 1091 (4th Cir. 1993), cert. denied, 114 S. Ct. 2134 (1994); see Davis, supra note 14, at 622 ("Indeed, although some courts have concluded that a nonfunctionality requirement is necessary to prevent a statutory clash between the utility patent and trademark laws, others have been less inclined to recognize such a conflict."); Pollack, supra note 13, at 262 ("Based upon a conclusion that Shakespeare's trademark was functional as defined in trademark law, Pollack argues that the Fourth Circuit unconstitutionally found the mark valid."). Silstar was a difficult case to say the least: The Fourth Circuit held there that incontestability under the Lanham Act was available even as to functional elements of registered trade dress. Debatable as a doctrinal matter, the case seems particularly egregious when considered against the "limited times" provision of the Intellectual Property Clause.

This is indeed the reading of Silstar that Professor Pollack clearly comes to in her work. Her article is, in a sense, an expanded set of notes for a brief explaining why the decision, in her blunt phrase, "is unconstitutional" on just such grounds. Id. This is in no sense to disparage her achievement, which is considerable in no small part precisely because of the remarkable degree of focus and control she brings to her analysis.

Davis meanwhile agrees, of course, as to the relationship between the "limited times" provision of the Clause and Silstar. See Davis, supra note 14, at 622 ("Although it may be true that 'it is the province of patent law, not trademark law, to encourage invention by granting inventors a monopoly over new product designs for a limited time,' it is equally true that, as a matter of statutory law, there is nothing to prevent Congress from altering this balance."). But as I read his work, his criticism of Silstar also is predicated on somewhat wider principles:

In restricting recovery for infringement to cases in which a plaintiff (1) uses in commerce (2) a nonfunctional trade dress and can prove (3) that the trade dress is a distinctive indicator of origin and (4) that a defendant has employed a confusingly similar trade dress, federal trade dress law obviously differs in significant respects from its utility patent counterparts. Nevertheless, however desirable the other prerequisites may be to prevent a statutory conflict with federal utility patent legislation, only the second-nonfunctionality-has a textual basis in the Constitution and none of the Court's decisions has suggested that satisfaction of the other factors will obviate this requirement. As long as it does not reach utilitarian features, the Lanham Act is consistent with the Intellectual Property Clause. The Act's extension to functional elements at the behest of trade dress owners, however, would create a regime of protection directly overlapping that contemplated by the Clause, independent of any other requirements that may be imposed on plaintiffs.

Thus, in light of the holding in Compco and its progeny that the protection of functional designs is subject to constitutionally mandated temporal limitations, prohibiting the copying of these designs under the Act would create more than conflict with statutory patent law. Rather, as one court has noted in determining the eligibility of the plaintiff's product configuration for federal trade dress protection, "[a] prohibition against copying under such circumstances would contravene the policy ... of the Constitution which gives the public free access to those materials in the public domain." Because the Lanham Act can no more abrogate constitutional mandates than can other federal legislation, its potentially perpetual protection does not reach individually functional elements-not only because the Act does not expressly address them, but became it cannot do so.

Id. at 641-43.

Davis's reference to the potential for "perpetual protection" does invoke the "limited times" provision. But the real thrust of his remarks has to do with the broader implications in the Clause which speak to the essential underlying relationship between "exclusive rights" and the public domain. Limitations as to time are but a part of the Clause's larger apparatus of prerequisites. 
the memorable phrase employed by one commentator whom Davis cites, cannot suffice against the Clause's constraints, no matter how cleverly wrapped in the mantle of the Lanham Act or the Commerce Clause they may be. ${ }^{63}$

This is, I believe, the general thesis implicit throughout Davis's essay. Pollack's scholarship in her essay is less susceptible to large readings, but her earlier work certainly suggests that she would agree with the thought behind Davis's work, if not perhaps entirely with its expression. ${ }^{64} \mathrm{It}$ is, in any event, if I read it correctly, a thesis with which I whole-heartedly concur.

\section{B. Federalism and Its Limitations}

No doubt the states may be preempted by federal legislation through the operation of the Supremacy Clause, as, for example, in the Copyright Act of 1976 via section $301 .^{65}$ But are the states bound directly by the constraints in the Clause?

Experienced intellectual property lawyers can be counted on for close familiarity with the relevant cases to date. They begin with Sears-Compco ${ }^{66}$ and Brulotte, ${ }^{67}$ come forward through Graham v. John Deere, ${ }^{68}$ Lear, ${ }^{69}$ Goldstein, ${ }^{70}$ Kewanee, ${ }^{71}$ and Aronson, ${ }^{72}$ and end for the time being with Bonito Boats. ${ }^{73}$ These cases amount to a canon, and I will not rehearse them here. Both Pollack and Davis agree as to their general relevance. ${ }^{74}$

Davis appears to conclude that direct preemption does not survive the evolution of these cases. ${ }^{75}$ Compco had suggested, in a celebrated passage much discussed at the time, that preemption worked directly via the Intellectual Property Clause, ${ }^{76}$ but Goldstein limited that suggestion so substantially as to preclude it in the opinion of most who read the later case. ${ }^{7}$ And Bonito Boats, in Davis's view, "closed the door" on the issue in a passage he cites at length-from which a single sentence suffices to convey the gist of what evokes

63. Christopher A. Mohr, Gray Market Goods and Copyright Law: An End Run Around K-Mart v. Cartier, 45 CATH. U. L. REv. 561 (1996).

64. Pollack, supra note 30 , at 1396-97, 1494.

65. 17 U.S.C. $\$ 301$ (1996); David E. Shipley, Publicity Never Dies; It Just Fades Away: The Right of Publicity and Federal Preemption, 66 CORNELL L. REV. 673 (1981).

66. Sears, Roebuck \& Co. v. Stiffel Co., 376 U.S. 225 (1964); Compco Corp. v. Day-Brite Lighting, Inc., 376 U.S. 234 (1964).

67. Brulotte v. Thys co., 379 U.S. 29 (1964).

68. 383 U.S. 1 (1966).

69. Lear, Inc. v. Adkins, 395 U.S. 653 (1969).

70. Goldstein v. California, 412 U.S. 546 (1973).

71. Kewanee Oil Co. v. Bicron Corp., 416 U.S. 470 (1974).

72. Aronson v. Quick Point Pencil Co., 440 U.S. 257 (1979).

73. Bonito Boats, Inc. v. Thunder Craft Boats, Inc., 489 U.S. 141 (1989).

74. See Davis, supra note 14, at 609-18; Pollack, supra note 13, at 304-10, 317-19.

75. See Davis, supra note 14, at 618 ("Indeed, Bonito Boats closed the door on an issue that the Court's post-Compco decisions had not expressly resolved, namely whether the Intellectual Property Clause operates as an affirmative restriction on state action.").

76. Compco Corp. v. Day-Brite Lighting, Inc., 376 U.S. 234 (1964); Derenberg, supra note 6.

77. Goldstein v. California, 412 U.S. 546 (1973); see, e.g., Paul Heald, Federal Intellectual Property Law and the Economics of Preemption, 76 IOWA L. REV. 959 (1991). 
his pessimism: "Our decisions since Sears and Compco have made it clear that the Patent and Copyright Clauses do not, by their own force or by negative implication, deprive the states of the power to adopt rules for the promotion of intellectual creation within their own jurisdictions." 78

But it is one thing to preempt the states altogether from acting in matters affecting intellectual property, as Compco might have done, and quite another to suggest that the Clause may not still limit them in whatever fashion it may limit Congress. The latter is preemption (if the term applies at all) of a very different stripe.

Nothing said in Bonito Boats or elsewhere suggests explicitly that the states may not be obliged by the Intellectual Property Clause to observe, when acting to encumber the public domain, the same fundamental limits as circumscribe congressional action of like kind. Preemption of a more traditional sort in such circumstances then would have to do merely with a suitable state deference in the presence of federal legislation. This was the case with the Patent Act in Bonito Boats, for example. ${ }^{7}$ Absent such legislation, however, the states would be free to act as Bonito Boats also suggests-but only on the presupposition of compliance, it should be emphasized once again, with the limits embedded in the Clause.

The closer precedents for a state-federal relationship of this sort are in the Bill of Rights, as Davis himself notes in an earlier passage in his work. ${ }^{80}$ And the closest precedents of all are the now-some-thousands of First Amendment cases, most of them no more than a few decades old, and all of them decided in response to exigent circumstances arguably equivalent in urgency, if not precisely equivalent in issues, to the circumstances that prompt us now to imagine a new role for the Intellectual Property Clause. ${ }^{81}$

78. Davis, supra note 14, at 618 (quoting Bonito Boats, 489 U.S. at 165).

79. Bonito Boats, 489 U.S. at 152.

Thus our past decisions have make it clear that state regulation of intellectual property must yield to the extent that it clashes with the balance struck by Congress in our patent laws. The tension between the desire to freely exploit the full potential of our inventive resources and the need to create an incentive to deploy those resources is constant. Where it is clear how the patent laws strike that balance in a particular circumstance, that is not a judgement the Id. States may second-guess.

80. See Davis, supra note 14 , at 613 n.82.

Although, like the Intellectual Property Clause, the Bill of Rights on its face applies only to the federal government, the Supreme Court, beginning in Palko v. Connecticut, 302 U.S. 319 (1937), expressly has held that certain provisions of the first eight amendments apply to the states through their 'incorporation' into the Due Process Clause of the Fourteenth Amendment. Viewed in the light of the Warren Court's acceleration of this process in the early 1960's, Compco's direct reference to the Intellectual Property Clause as a ground for invalidation of a state practice, rather than to the interplay of a federal statute and the Id. Supremacy Clause, is hardly surprising.

81. See Lange, supra note 5, at 133-34.

Today the First Amendment is all but omnipresent in our lives; we live as though we had always lived within a system of free expression; and indeed, I would say, in a sense, we always 
Pollack, meanwhile, embraces a view of direct preemption that is not far from this model. She does not consider the First Amendment at all, however, preferring instead to envision a role for what she calls "the dormant Intellectual Property Clause" that parallels the development of "the dormant Commerce Clause." 82

There is no compelling evidence, she observes by way of beginning, to suggest that the states were not meant to share in dispositions of intellectual property from time to time. ${ }^{83}$ It seems more probable than not that the Intellectual Property Clause "was intended, or originally considered, to be a non-exclusive grant to Congress." 84

How regrettable, then, that the Court should have muddled the field so badly after Compco. Though Goldstein did indeed hold "that the grant to the federal government is non-exclusive .... It failed to discuss the possibility of anything like a dormant Copyright Clause, but instead skipped directly to the standard [source of] statutory preemption, the Supremacy Clause"

While "it is difficult to see how the concurrent exercise of the power to grant copyrights by Congress and the States will necessarily and inevitably lead to difficulty,"

did-but not because of the First Amendment: we must remember that the First Amendment did not begin to be construed until 1919, at the close of the Great War, when repeated prosecutions of dissidents forced us to think in more formal terms about what it was to be free. We found it useful then to envision an expanded First Amendment precisely because our circumstances justified a formal resolution of that dilemma. . . As was true in 1919 with the First Amendment, so now it may be with the Intellectual Property Clause: exigent necessity justifies us in envisioning new, more formal uses for a dormant provision of the Constitution.

Id.; cf. William W. Van Alstyne, The Second Amendment and the Personal Right to Bear Arms, 43 DUKE L. J. 1236 (1994) (developing much the same argument more elegantly and at greater length-though to be sure in a decidedly different context).

82. See Pollack, supra note 13, at 313 ("The Intellectual Property Clause ... is addressed to Congress; it binds only Congress. The Clause does not mention national uniformity; it does not mandate national uniformity. No parallel clause bars state action; the Clause, itself, does not bar state action. However, this analysis ignores the possibility of a dormant Intellectual Property Clause. After all, the Commerce Clause is addressed to Congress, does not mention uniformity, and lacks a parallel anti-state-action clause."). Pollack offers four possible justifications for how the Intellectual Property Clause may apply to the states:

In roughly descending order of analytic rigor, they are: (1) statutory/constitutional preemption created by the Intellectual Property Clause in combination with any federal legislation under that Clause prevents state action in this realm, (2) constitutional preemption by the Intellectual Property Clause itself prevents state regulation, (3) a dormant Intellectual Property Clause prevents state intellectual property regulation, and (4) the intersection of the Intellectual Property Clause and the dormant Commerce Clause prevents such state regulation. Id. at 301 .

This is, by her own account, the portion of her work she finds "the most interesting and the most theoretical." Id. at 261. My summary of her work here, meanwhile, will be brief and no doubt less than the enterprise deserves. And I propose to cheat a bit: I will deal at length only with that portion of the work that I find most satisfactory from the point of view of my own thinking on the subject. The reader is forewarned accordingly.

83. See id. at 301 ("The Intellectual Property Clause does not mention the states. Nor does it declare congressional power to be exclusive or tied to nationally uniform laws. No constitutional clause expressly prohibits state legislation over intellectual property.").

84. Id.

85. Id. at 305-06. 
the Court erred in believing that " $[\mathrm{n}] \mathrm{o}$ reason exists why Congress must take affirmative action either to authorize protection of all categories of writings or to free them of all restraint." The usefulness of a dormant Intellectual Property Clause would be to invalidate state statutes which individually interfere with constitutional values. ${ }^{86}$

And this is so, Pollack goes on to say, even if, originally and in plain text, the Clause was directed solely to Congress:

After all, the Commerce Clause is addressed to Congress, does not mention uniformity and lacks a parallel anti-state-action clause ... . If, as Supreme Court dicta consistently declare, eventual dedication to the public is the central concern of the Intellectual Property Clause, Learned Hand is correct in asserting that state law allowing perpetual protection of any "writing" or "discovery" is unconstitutional because it "prejudice[s] the interests of the other states" and of the states united.

Some broad power delegated non-exclusively to the federal government might require for its effectiveness that states be barred from some small group of actions, but not all actions, in that area. I originally called this broad power a "dormant Intellectual Property Clause" because it involves the type of analysis involved in dormant Commerce Clause jurisprudence: a case-by-case analysis, as opposed to a blanket rejection of state action in a broad area.

As a textual matter, the Intellectual Property Clause is a more sensible place for such case-by-case analysis than is the Commerce Clause. Although the Commerce Clause does not state why or how Congress should regulate commerce, the Intellectual Property Clause gives both a purpose-to promote the progress of science and the useful arts-and a method, by supplying, for limited times, exclusive rights to authors and inventors. This allows courts to easily decide whether a state has violated the clause in the absence of statutory preemption. "Limited times" is the clearest of the textual fences in the clause. Therefore, whatever state intellectual property regulations may be allowable, granting perpetual [authors' or inventors' exclusive rights] should be held unconstitutional regardless of congressional action or inaction. ${ }^{87}$

This is, I think, a singularly powerful argument, one that offers the prospect of a reasonably comprehensive response to the exigent need for more secure constitutional authority in the state fields of intellectual property. What is compelling in this version of the role Pollack envisions for the Clause (beyond the frank recognition that it has not yet come into its own) is the possibility that it may still grow, and grow directly in its own terms as individual cases and circumstances require, thereby acquiring meaning that the text itself would not immediately suggest. ${ }^{88}$

86. Id. at 306 (emphasis in original; internal quotation omitted).

87. Id. at 313-15 (footnotes omitted).

88. Meanwhile, the alternatives Pollack suggests seem less attractive. There are three. One appears to contemplate the sort of comprehensive preemption that Goldstein, Kewanee, and Bonito Boats all seem to rule out. See id. at 315 ("One could label the dormant Intellectual Property Clause ... a preemption turning on the mere existence of any federal statute, rather than one turning on the type, content, or extent of a federal statue.").

A second imagines that the Clause might apply when (but only when) any congressional legislation has been enacted touching upon any of the constraints reflected in the Clause. This is Pollack's own favorite, though she does not say why. See id. ("The Intellectual Property Clause gives both a purpose-to promote the progress of science and the useful arts-and a method, by supplying, for limited times, exclusive rights to authors and inventors. This allows the courts to easily decide whether a statute has violated the clause in the absence of statutory preemption.").

A third alternative envisions an explicit linkage between the Intellectual Property Clause and the dormant Commerce Clause, thereby allowing the latter to supply, by way of preemption, what the former cannot quite muster. See id. at 319 ("Instead of asking the Court to change its interpretation 


\section{What Does the Clause Mean?}

Does the Clause lend itself to a search for central meaning?

Pollack acknowledges that the Supreme Court has repeatedly suggested that "eventual dedication to the public is the central concern of the Intellectual Property Clause." ${ }^{19}$ And she observes that the Clause must be interpreted in ways that are responsive to its text, rather than in terms having their origins in particular doctrines. ${ }^{90}$

In the end, though, she is concerned more with the mechanisms of preemption than with the substance of the Clause itself. Hers is an essay about the Constitution, about the relationships among its constituent parts-in short about constitutional process; and if there is a larger meaning in her view of the Clause, then perhaps, like Professor Maine's common law, it may be secreted among the interstices of procedure.

Davis begins, on the other hand, with Feist Publications v. Rural Telephone Service Co. ${ }^{91}$ a case in which, he observes at the outset, "the Court recognized in the copyright context an apparent constitutional right to copy separate and independent of any such right that may be found in the [Copyright Act of 1976]." ${ }^{, 2}$ And this leads in turn to a large proposition indeed about meaning:

It is the thesis of this article that the constitutional principles upon which Feist rests are equally applicable in another area, namely federal trade dress protection under the Lanham Act. Specifically, this article argues that Feist merely reaffirmed the Court's prior holdings in cases involving product configurations that the Intellectual Property Clause creates and defines a public domain that trumps all federal intellectual property legislation and not just that in Feist. ${ }^{93}$

Davis moves quickly to sketch in the framework of his design. Beginning with the Court's opinions in The Trademark Cases and Graham v. John Deere (in the originality requirements of which he appears to find, as I do, a basic jurisprudence of the public domain ${ }^{94}$ ), he moves next to an observation close to the center of both Bonito Boats and Feist: namely, that "it is 'implicit in the Clause itself that free exploitation of ideas will be the rule, to which the protection of [intellectual property] is the exception . . .."'95

of the Intellectual Property Clause, we could ask the Court to hitch that Clause to the acknowledged dormant commerce clause-as Goldstein murkily suggested.").

No doubt these alternatives have much to offer in terms of theory, and I daresay others will find them more intriguing than I do. In my view the first is less plausible, after Bonito Boats, and the other two are so contingent as to be unpromising in development.

89. Id. at 286-87.

90. See id. at 290 .

91. 499 U.S. 340 (1991).

92. Davis, supra note 14 , at 596.

93. Id.

94. Id. at 603-15; see also David Lange, Sensing the Constitution in Feist, 17 U. DAYTON L. REV. 367,372 (1992). In a separate section of his essay, Davis appears also to believe that the description of authorship in Burrow Giles v. Sarony is also necessary to a full understanding of originality and the public domain, and I would agree with that suggestion as well. See Davis, supra note 14, at 631 .

95. Davis, supra note 14, at 618 (quoting Bonito Boats, 481 U.S. at 151). 
Equally large consequences follow from this insight, and in the copyright context Davis sees them clearly:

The Court's constitutional analysis [in Feist] did not stop with reaffirming that the Intellectual Property Clause imposes substantive restrictions on the federal protection of intellectual property. On the contrary, the Court went on to offer guidance on how to apply the constitutional right to copy to works consisting of both protectable and unprotectable elements. On this issue, protection could not extend to unoriginal factual material even if that material was "commingled" with original selection and arrangement. Rather, [a] factual compilation is eligible for copyright if it features an original selection or arrangement of facts, but the copyright is limited to the particular selection or arrangement. In no event may copyright extend to the facts themselves.

Applying this rule to the facts before it, the Court concluded that the putatively original aspects of the plaintiff's arrangement-the alphabetization of the directory's factual information-fell well below the constitutional level of originality required to warrant even "thin" copyright. In light of the plaintiff's inability to demonstrate that any aspect of its work was original, the entire work was thus subject to copying. ${ }^{96}$

So far, so good. I have long supposed that an adequate recognition of the public domain requires a presumption away from, rather than toward, protection: Doubtful cases ought always to be resolved in favor of the party in reliance upon rights grounded in the public domain. ${ }^{97}$ This is fairly implicit in what the Court said in both Bonito Boats and Feist; Davis appears at first to agree with it in the context of trade dress as well. Thus he concludes, near the end of his work: "Despite the absence of express guidance from the Supreme Court .... Courts can and should recognize that, just as the Constitution restricts the ability of copyright owners to protect public domain elements of their works, it concomitantly restricts the ability of trade dress owners to do the same." 98

But Davis's analysis seems more problematic as he develops his understanding of the deeper meaning in the Clause and its application to trade dress. The difficulty, at least in my reading of his thesis at least, begins with his handling of the concepts of functionality and nonfunctionality. Of course these are standard doctrinal terms in trademark law, and while cases by the score turn on their construction in particular circumstances, still the basic definitions are not ordinarily in issue. ${ }^{99}$

Considerable doubt arises, however, when one equates these terms in their general usage with such terms as "originality," "authorship," or "creativity," terms central to copyright; or "novelty," "utility," and "nonobviousness," the counterpart terminology employed in patent law. The copyright and patent terms have all been sanctioned through usage as having constitutional

96. Id. at 636 (emphasis added; internal quotations omitted).

97. See Lange, supra note 38 , at 150.

98. Davis, supra note 14 , at $649-50$.

99. For the sake of argument, I will accept Davis and Pollack's usage as to functionality (drawn in each of their works from the Court's opinion in Inwood Labs): "In general terms, a product feature is functional if it is essential to the use or purpose of the article or if it affects the cost or quality of the article." Inwood Labs., Inc. v. Ives Labs., Inc., 456 U.S. 844, 844 (1982). 
significance derived from the Clause: The Trademark Cases, Burrow-Giles, Bleistein, Graham, Mazer v. Stein, and Feist have said as much. ${ }^{100}$

The same cannot be said, however, of functionality and nonfunctionality. These terms have a considerably slighter claim to constitutional significance, despite their appearance in occasional cases in which the Clause has also figured, such as Sears-Compco and Bonito Boats. The reason is straightforward enough: As Davis and Pollack themselves acknowledge, the Court has never offered an extended opinion, in dictum or otherwise, as to the relevance of these terms under the Constitution. ${ }^{101}$

Davis may conclude too much, then, with respect to the relationships among functionality, nonfunctionality, and the public domain. Discussing recent Seventh and Second Circuit cases, ${ }^{102}$ he observes:

These decisions recognize the converse of Feist, namely that liability may attach once a defendant's appropriation has moved beyond the scope of the right to copy created by the Intellectual Property Clause, even if an otherwise functional product configuration is concemed. Because, according to its text and under The Trade-Mark Cases' application of that text, the Clause's "for limited Times" language is directly applicable to "invention and discovery," this restriction is inapplicable to nonfunctional elements that do not result from "sudden invention," "genius," or "laborious thought." Thus, although there may be "absolutely nothing legally or morally reprehensible about exact copying of things in the public domain," full recognition of the Clause in the trade dress context would not mean "that the copying of a functional feature . . . protects a defendant who has also reproduced nonfunctional features." Nor would it preclude liability if a defendant's copying of entirely functional features is coupled with separate and independent acts of unfair competition such as "palming off," false advertising, or deceptive trade practices. On the contrary, relief under these circumstances is not only permissible, but appropriate. ${ }^{103}$

The ultimate proposition here is unassailable up to a point: Palming off and the other traditional offenses in trademark law may be addressed and corrected, short of forbidding copying simpliciter. Sears and Compco both allowed as much, ${ }^{104}$ and so does Bonito Boats. ${ }^{105}$

100. See supra notes 66-73 and accompanying text; see also Mazer v. Stein, 347 U.S. 201 (1954). I do not say the terms considered in these cases occupy the field, but clearly they do have significance. They have been drawn from doctrinal practice; they also have acquired independent standing as constitutional terms of art.

101. See Pollack, supra note 13 , at 265 ("The courts have refused to grant trademark protection to 'functional' features. This judicial fiat sensibly prevents exclusive property in the 'useful arts' without the need to meet the high criteria of the utility patent statutes and without the time limitations imposed on patent rights. Congress has never spoken on this issue ... [and] the Supreme Court has never directly considered the rule's legitimacy .....); Davis, supra note 14, at 625 ("To date, the Supreme Court has declined to provide express guidance on this issue.").

102. See Vaughan Mfg. Co. v. Brikam Int'l, Inc., 814 F.2d 346 (7th Cir. 1987); Le Sportsac, Inc. v. K Mart Corp., 754 F.2d 71 (2d Cir. 1985).

103. Davis, supra note 14, at $651-52$ (emphasis added).

104. See Sears, Roebuck \& Co. v. Stiffel Co., 376 U.S. 225, 232 (1964) ("Doubtless a State may, in appropriate circumstances, require that goods, whether patented or unpatented, be labeled or that other precautionary steps be taken to prevent customers from being misled as to the source, just as it may protect businesses in the use of their trademarks, labels, or distinctive dress."); Compco Corp. v. DayBrite Lighting, Inc., 376 U.S. 234, 238 (1964), ("[W]hile the federal patent laws prevent a State from prohibiting the copying and selling of unpatented articles, they do not stand in the way of state law, statutory or decisional, which requires those who make and sell copies to take precautions to identify 
But are nonfunctional elements in trade dress inevitably protected against copying simpliciter under the Clause? Trademark and unfair competition law today, in the wake of Professor Schecter's insight, ${ }^{106}$ might easily allow as much, in substance if not in form. ${ }^{107}$ And that is exactly why we need the more important insights provided by Feist and by Davis's own powerful earlier analysis.

As I read the implications in Feist, protecting nonfunctional elements against copying simpliciter in trademark law would have to depend on finding an equivalency in constitutional significance between nonfunctionality, on the one hand, and such elements as originality, novelty, nonobviousness, and the like, on the other. When such significance is present in nonfunctional elements, the law might then protect against copying as such, though only "for limited times." When nonfunctionality does not rise to an equivalent level of significance in constitutional terms, however, then it may not be protected against copying simpliciter at all. Period. That is indeed what Feist suggests, as Davis himself is at pains to demonstrate, and one cannot simply assume it away in the interest of continued coherence in trademark law and its accustomed practices. ${ }^{108}$

their products as their own.").

105. See Bonito Boats, Inc. v. Thunder Craft Boats, Inc., 489 U.S. 141, 165 (1989) ("[T]he Patent and Copyright Clauses do not, by their own force or by negative implication, deprive the states of the power to adopt rules for the promotion of intellectual creation within their own jurisdictions.").

106. See Schecter, supra note 34 .

107. Many trademark lawyers will resist this proposition: Copying, they will say, is never forbidden simpliciter in trademark law; copying alone is irrelevant except in the company of confusion or something equivalent to it that trademark law touches upon. But I would argue that resistance to the concept of copying simpliciter today is either naive or disingenuous. In my experience, trademark practice, as opposed to trademark theory, increasingly turns on copying itself, from which inferences of the necessary juridical wrongs then follow after the fact. See additional development of this point, infra note 136 and accompanying text.

108. What is suggested here is a revised matrix of theory and remedies in those trademark cases in which copying or appropriation plays a central role, but in which a finding of constitutional equivalence, on a spectrum running from originality and minimal creativity up to novelty and nonobviousness, is absent. It is important to remember that trademark interests are not more obviously like those in patent law than they are like those in copyright law; they are a kind of hybrid. The entire constitutional spectrum is therefore relevant until trademark law acquires its own constitutional terminology.

An elaboration of this suggestion would be the work of another complete essay, but the rudimentary outlines can be sketched in here.

Under an appropriate reading of Feist, copying (appropriation) as such may not be forbidden in the circumstances described above, whether the contested trademark element is functional or nonfunctional; nor may "weak" inferences of "likely confusion" be drawn from mere copying (appropriation). But copying (appropriation) in the service of actual passing off might be regulated vigorously so as to limit the likelihood of confusion-by imposing such constraints as labeling, disclaimers, and the like. And in the presence of something amounting to insurmountable actual confusion or deliberate misrepresentation, I think, on balance, that even Feist would allow copying (appropriation) to be sharply curtailed, if not forbidden altogether. After all, copyright and patent rights do not confer immunity against all serious social harms unrelated to affirmative public domain interests.

For additional, useful readings along the lines suggested here, see Gleiberman, supra note 30, at 2050-55; Reichman, supra note 40, at 395-97. Cf. Michael B. Gerdes, Getting Beyond Constitutionally Mandated Originality as a Prerequisite for Federal Copyright Protection, 24 ARIZ. ST. L.J. 1461, 1472 (1992). 
Davis suggests that nonfunctional elements in trade dress may escape the constraints imposed by the Clause because the Clause is addressed to elements that "result from 'sudden invention,' 'genius,' or 'laborious thought."' But this is, I suggest, a misreading of The Trademark Cases. The Court there was speaking of elements to be expected in copyright and patent law. ${ }^{109}$ Trademark law was not exempted from the Clause because it could not contain elements of this sort. Instead, trademark law at the time simply did not protect against copying simpliciter. Had the trademark law been otherwise in that day, the Court would have had to think again, at least under the theories Davis advances in his work-not only about the availability of the Clause as a source of congressional power to enact trademark legislation, but more to the point, about the necessity of such legislation to accord with the threshold elements the Court took for'granted in copyright and patent law.

Pollack supposes, meanwhile, that nonfunctional marks may be protected without limitation as to term, whether or not they may reflect elements of originality, novelty, or nonobviousness. ${ }^{110}$ In this sense she accords such marks even greater latitude than does Davis. ${ }^{111}$ Her analysis of the relationship between "copying" and "exclusive rights" differs from Davis's so substantially, however, as to preclude criticism along corresponding lines. ${ }^{12}$ I will not take the time here to chart the ways in which Pollack arrives separately as to a rough accord on the role to be played by nonfunctionality. Suffice it to say merely that she too attributes a constitutional significance to nonfunctionality that is less well-developed than even her considerably different thesis requires. ${ }^{113}$

109. See supra, notes $15-16$ and accompanying text.

110. Pollack, supra note 13, at 293.

111. See id. at 288-97.

112. See id. at $289-92$ n.163. Indeed, the former term ("copying") has, for Pollack, no necessary constitutional significance at all, coming as it does, she thinks, from doctrines internal to copyright; and therefore amounting to a "problem," she asserts, only in the presence of a statute triggering preemption under 301 of the Copyright Act. 17 U.S.C. \& 301 (1988). I disagree; like it or not, Feist has lent the concept of copying a larger constitutional meaning than it otherwise has had-much as the Court's opinion in New York Times $v$. Sullivan lent sanctity to the once-insignificant common law concept known as "actual malice." 376 U.S. 254 (1964). The problem with Pollack's approach to the Clause on this score is that "exclusive rights" inevitably take on the coloring of the cases that address them; it is never the other way around.

113. Pollack, supra note 13 , at 293 :

Trademarks do not have the non-obviousness of "discoveries;" they are not originated by

"inventors." Furthermore, the companies using the trademarks may not have created them; therefore, no rights are given to "inventors." Their purpose is to prevent fraud in the marketplace, not advance science and the useful arts. While trademarks do grant exclusive rights, their immortality does not violate the Patent Clause.

Id. Her reliance on the concept of "mere descriptiveness" is also under-developed. Id. at 294 ("The patent-based restriction on functional marks is parallel to the copyright-based restriction on merely descriptive marks."), 326-27 ("The Constitution bars a congressional grant of perpetual, exclusive rights in both (1) functional trademarks and (2) merely descriptive trademarks that are simultaneously 'writings.' The Intellectual Property Clause must be applied to the states at least to the same extent. Therefore, neither the federal government nor the states may create such protection.") Again, that term has meaning in the context of trademark law, but it has little or none at all in the constitutional setting. 
Additional questions can be raised concerning the authors' assumptions as to functionality. Davis concludes that functional elements are always subject to the limits imposed by the Clause and should therefore receive only "thin" protection at best, roughly equivalent to the protection accorded to compilations of fact under Feist. ${ }^{114}$ He seems nonetheless to suggest that protection could be had in the arrangement (compilation) of functional features, as the Second Circuit held in Le Sportsac. ${ }^{115}$ But would that result survive an application of Feist's disdain for merely low-level arrangements of facts? After all, "common sense tells us that 100 facts do not magically change their character merely because they are gathered together in one place."116 In some circumstances, it would seem that Le Sportsac would lead to impermissible results under the Clause.

Pollack's view of functionality is somewhat more guarded, and does include a preliminary inquiry into the existence of novelty or some equivalent. But she is willing to entertain the prospect in this context, as Davis does with respect to nonfunctionality, that a mark "below ... standards of patent creativity" might be accorded "exclusive rights" for unlimited times. Such a result, I would argue once again, would at least contravene the principal argument Davis raises under Feist. In the end, however, she concludes that the Clause probably would apply, and so the issue is mooted. ${ }^{117}$

No less troublesome, meanwhile, is the fact that both authors ignore aesthetic functionality, Davis by implication and Pollack explicitly: "Neither aesthetic functionality nor communicative functionality present the constitutional problem addressed in this article."118

Perhaps this seems fair enough on first impression; the work is theirs, after all, and surely they are free to design its scope as they please. Still, I cannot see how a satisfactory resolution of the questions they have raised about nonfunctionality and functionality can be complete unless aesthetic functionality and its close counterparts are considered as well.

Pollack is certainly correct in noting a wide-spread resistance to aesthetic functionality. ${ }^{119}$ But that does not mean that the concept is not in fact related both immediately and directly to the more "acceptable" form of functionality

114. See Davis, supra note 14, at 649 ("Even upon the most cursory examinations, these decisions reflect a 'thin' conception of trade dresses composed of individually functional features that is equivalent to the 'thin' copyright covering factual compilations such as that at issue in Feist.").

115. See id. at 650 ("Because "particular features may become an indication of source even though the entire product shape does not meet the [nonfunctionality] criteri[on],' recognition of a thin conception of trade dress would not preclude plaintiffs from protecting individually nonfunctional features or the nonfunctional gloss covering arrangements of functional features.").

116. Feist Publications, Inc. v. Rural Telephone Co., 499 U.S. 340, 345 (1991).

117. See Pollack, supra note 13 , at 293 . It is not clear whether she entertains the same debate with respect to "merely descriptive" marks that do not amount to "writings"; her conclusion suggests that she may suppose that in such cases the mark might be given protection for unlimited times. See also id. at 326-27.

118. Id. at n.36.

119. Id. (quoting 1 MCCARTHY, supra note $24, \S 7.26[4]$ [b], at 7-137 to -138). 
that she and Davis address. The conceptual kinship is inescapable, I'm afraid, and despite Pollack's suggestion to the contrary, there is nothing really "esoteric" about it. It is merely awkward, particularly for the practicing trademark bar and the judiciary, ${ }^{120}$ and their resistance is, I think, a function of what the late Harry Kalven liked to call "an insight more important than we can use."

Were we to accept aesthetic functionality as readily as we accept utilitarian functionality, we might be forced in time to recognize a pair of most awfully uncomfortable truths: namely, that much of contemporary trademark law probably could not stand as practiced; and second, that the distinctions we have presupposed among copyright, trademarks, and patent law are not merely ephemeral and illusory, but are now constitutionally insupportable as well. The implications in such a result would be remarkable, to say the least.

In short, then, Pollack and Davis have opened a Pandora's Box through the combined effort of their analyses. Awkward, uncomfortable, and remarkable conclusions are bound to follow. An inevitable consequence of a dormant Intellectual Property Clause is that fresh meanings not only may, but certainly will, cut across the field in ways we have not yet begun to imagine.

\section{III}

The questions I have raised about these authors' works should not be mistaken for ingratitude. Quite the contrary. They have offered a framework for analysis in contemporary trade dress cases that could lead courts to a useful and reassuring reconciliation among intellectual property doctrines now much estranged.

A single case will suggest the need for such a framework and will illustrate as well how the theories Pollack and Davis have advanced might be employed.

In Romm Art Creations v. Simcha International, Inc, ${ }^{121}$ the plaintiffs alleged trade dress infringement in fine art posters, claiming nonfunctionality and confusion. In fact, however, no one who studies the court's opinion in the case can sensibly imagine that confusion over trade dress was really at the heart of the matter. What was at issue in Romm Art was copying simpliciter; nonfunctionality and confusion made their way into the case, and into the court's opinion, only because, copyright not being available to the plaintiffs (for reasons not spelled out in the opinion), the complaint had perforce to be

120. RESTATEMENT, supra note $33, \S 17$, cmt. c ("When aesthetic considerations play an important role in the purchasing decisions of prospective consumers, a design feature that substantially contributes to the aesthetic appeal of a product may qualify as 'functional.' As with utilitarian design features, however, the fact that the design performs a function by contributing to the aesthetic value of the product does not in itself render the design ineligible for protection as a trademark."); see Gleiberman, supra note 30 , at 2044-50.

121. 786 F. Supp. 1126 (E.D.N.Y. 1992). 
brought under section 43(a) of the Lanham Act instead. ${ }^{122}$ And here, I think, we have a paradigm of the sort of expansionism rampant everywhere in trademark and unfair competition law in our time.

But let the reader judge. These were the facts: An Israeli artist named Tarkay created a series of works suitable for sale as "fine art posters." 123 His works were pleasing in appearance and sold well in the markets for such works. ${ }^{124}$ Meanwhile, a second artist known as "Patricia" created a second line of posters also suitable for sale in the same markets. Her works, also pleasing to look at, closely resembled Tarkay's in style. ${ }^{125}$ In style, indeed, they may or may not have been deliberately imitative of Tarkay. Tarkay alleged as much, though Patricia denied it. ${ }^{126}$

But their compositions certainly were not identical. Though similar in ideas and subject matter, the actual expression in the several works at issue in the case contained little in the way of similarities (except as dictated by style) and much in the way of differences. ${ }^{127}$

Had copyright actually been at issue, then, the plaintiff's case would have been difficult indeed. His claim of proprietorship in the style of the works would have been problematic at best; nor could he have claimed substantial appropriation of any of his protected expression, given the differences between the protectable expression in the compositions. From a copyright point of view, his case on the merits would have been weak.

What is more, given time, Tarkay's works would have passed into the public domain. Once there, they would have been available to Patricia, who might then have taken them and imitated them in whatever fashion she pleased. ${ }^{128}$

From within the hermeneutics of copyright, in short, the case is relatively straightforward. I am guided and constrained in thinking so by two centuries of influence brought to bear upon that body of doctrinal law by the Intellectual Property Clause. Originality, a limited term, eventual dedication to the public domain, and concomitant rights to copy or otherwise appropriate the work so dedicated-these are the consequences of the Clause's influence, far more deeply so than of the doctrinal law itself.

This has been a matter of the utmost importance to the continued development of copyright law. I have spoken of a First Amendment "waiting in the wings." 229 Others have written with increasing frequency of the potential for

122. Id. at 1131 (finding that plaintiffs had properly commenced their suit, "notwithstanding the lack of a copyright infringement claim").

123. Id. at 1130 .

124. Id.

125. Id. at 1131.

126. Id.

127. The works are offered and may be compared in ROBERT A. GORMAN ET AL, COPYRIGHT FOR THE NINETIES: CASES AND MATERIALS 822-23 (4th ed. 1993), or in JANE GiNSBURG ET al., TRADEMARKS AND UNFAIR COMPETITION LAW: CASES AND MATERIALS 610-11 (2d ed. 1996).

128. See 1 NimmER, supra note 7, \& 2.04[G] ("Under the current Act, therefore, works whose copyright term or terms have expired are obviously not protected.").

129. See supra note 46 and accompanying text. 
conflict between copyright and the First Amendment. ${ }^{130}$ I do not intend to rehearse their work in this essay, but it is perfectly clear, to me at least, that copyright has held the First Amendment at bay only because of the availability of such assurances in copyright law as I have noted above. Were these assurances to disappear from copyright, or be weakened through attrition or attenuation, I think it is unimaginable that copyright could survive against the adverse weight of the First Amendment. ${ }^{131}$

Even so, some indeed have argued that the First Amendment should be more immediately applicable to copyright than has been the case to date. I disagree, and strongly so. The First Amendment presupposes freedom of expression; intellectual property under the Constitution presupposes exclusive rights for limited times. The presumptions in First Amendment jurisprudence run in ways inappropriate to the presumptions in intellectual property. What intellectual property requires, I would argue, is not an expanded First Amendment, but an expanded Intellectual Property Clause, joined with the First Amendment in providing a comprehensive system of protection for individual proprietary rights in authorship and invention that ultimately will serve the public domain and freedom of expression alike. ${ }^{132}$

Contrast the foregoing analysis under copyright, meanwhile, with the very different analysis called for under trade dress doctrines.

Confusion is of course central in theory to trade dress litigation. ${ }^{133}$ In practice, however, confusion is often little or nothing more than a makeweight, observed ex hypothesi. Actual confusion is not required; a likelihood of confusion will do. ${ }^{134}$ And few cases present compelling proof even as to this

130. See, e.g., authorities cited, supra notes 42,46 .

131. See Nimmer, supra note 42 , at $1182-91$ ("It cannot be denied that the copyright laws do in some degree abridge freedom of speech, and if the First Amendment were literally construed, copyright would be unconstitutional."). However, based upon the eventual dedication of intellectual creations to the public domain and the limitation of the exclusive right to expression, copyright laws are able to survive against the First Amendment. As Nimmer points out, "if writers and other creators could not build upon the ideas of their predecessors, not only would free speech be stifled, but the creative processes themselves [and their eventual dedication to the public] would also be severely circumscribed." Id. at 1191; cf. Van Alstyne, supra note 46, at 1648-57. But see NIMMER, supra note 7, at § 1.09 (contemplating commerce clause power as an alternative source of authority for copyright); $c f$. Philip H. Miller, Life After Feist: The First Amendment, and the Copyright Status of Automated Databases, 60 FordHAM L. REV. 507, 509-12, 536-38 (1991).

132. See Lange, Sensing the Constitution in Feist, supra note 12, at $368 \mathrm{n} .4$; see also Coombe, supra note 43 , at $1876 \mathrm{n} .133$. I am unaware of any development of this argument in prior works, though the foundational insights seem obvious enough and may well have found earlier expression. I do remember encountering similar observations in a more recent work - but, alas, neither my research assistant nor I have succeeded in locating that work while completing this essay. In any event, I think the argument in this paragraph of the text deserves wider attention than it appears to have had, and I would be most grateful for additional citations or commentary.

133. 1 MCCARTHY, supra note $24, \S 8.03$ [1], at 8-28 ("The test of unfair competition in the case of a similar use of dress and packaging is whether there is a likelihood of confusion resulting from the total image and impression created by the defendant's product or package on the eye and mind of an ordinary purchaser.").

134. Id. ("[E]vidence of actual buyer confusion is not necessary in order to find a likelihood of confusion."). 
lesser requirement. Given common products and markets, such proof as there is usually turns on the degree to which the junior user's dress is "similar" to the senior users's dress. And if the proof additionally is to the effect that the junior user "intended" to appropriate the dress, then this is taken as additional evidence of a likelihood of confusion amounting to a presumption. ${ }^{135}$

In a typical case, then, a finding of copying tends to be equivalent to a finding of confusion or its likelihood. To be sure, there are other factors, and sometimes they can count heavily in the balance. ${ }^{136}$ But no experienced trademark lawyer fails to understand just how important copying simpliciter can be in the standard trademark case or, in contrast, just how subordinate the question of real confusion (as one's sainted Aunt Hattie would understand the term) usually is.

Few cases reveal these attributes of contemporary practice as transparently as Romm Art. The court's finding of a likelihood of confusion in that case turned on a thin soup of testimony purporting to establish actual confusion coupled with a presumption of law arising from the court's finding that the defendant intended to copy.

Even the substance of the testimony as to actual confusion was mainly to the effect that the works were "quite similar in general appearance" and had raised "concerns" in the minds of some who had seen them. ${ }^{137}$ Certainly the works were similar. But it was also true that they were quite distinctly signed, the one by Tarkay and the other by Patricia; ${ }^{138}$ it is hard to see how anyone but a cretin could actually have been in doubt as to which was which. And in fact the concerns appear to have occurred mainly to Tarkay's alarmed sales agents, rather than to the public. ${ }^{139}$ In the circumstances it was hardly surprising that

135. Romm Art, 786 F. Supp. at 1139 (citing Centaur Communications v. A/S/M Communications, 830 F.2d 1217, 1227-28 (2d Cir. 1987)) ("This consideration (whether the junior user intended to appropriate the mark or dress of the senior user) is relevant in determining likelihood of confusion. . .").

136. See Polaroid Corp. v. Polarad Elecs. Corp., 287 F.2d 492, 495 (2d Cir. 1961), cert. denied, 368 U.S. 820 (1961) (establishing eight criteria for finding confusion: (1) strength of the senior user's mark; (2) degree of similarity between the two marks; (3) competitive proximity of the two products; (4) likelihood plaintiff will "bridge the gap" (i.e., enter the market); (5) evidence of actual confusion; (6) junior user's good faith; (7) quality of junior user's product; and (8) sophistication of the purchasers).

137. Romm Art, 786 F.Supp. at 1138.

138. The signatures are readily visible in the works. See the examples collected in GORMAN ET AL. or GINSBURG ET AL., supra note 127. Some suggestion appears in the opinion to the effect that the works created by Tarkay may have been of an odd size. Romm Art, 786 F. Supp. at 1130 ("In contrast to other artists who were normally required to produce images in conventional sizes with standard two inch borders, Tarkay's works necessitated an alternative layout-with a single margin on either side or the bottom of the image."). The point is not developed, however, and even if it was so (and if one then supposed that confusion likely would have followed), the injunctive relief still clearly was broader than warranted by finding to that effect.

139. Romm Art, $786 \mathrm{~F}$. Supp. at 1138 (citing no examples of public confusion in support of evidence of actual confusion; rather, it offers plaintiff's testimony, defendant's expert testimony, and feedback from gallery owners as evidence of actual confusion). 
the sales agents would have been alarmed: Patricia's works, which were as pleasing to the eye as Tarkay's, sold for considerably less! ${ }^{140}$

Confusion, such as it was in the case, was augmented importantly by a finding of intentional copying. This is important because the Second Circuit has held that "intentional copying raises a presumption that the 'second comer intended to create a confusing similarity."'141 This is an utterly debased rule of law, if one thinks about it for more than a moment. An intent to copy in circumstances of this sort means nothing more, necessarily, than an intent to appropriate and, presumably, to compete.

One can easily see the problem with this kind of thinking, moreover, against the constitutional analysis proposed by Davis: any copying is automatically suspect under these rules of engagement. Feist, however, runs squarely to the contrary. A presumption to this effect is not merely illogical in its own terms; it also operates directly against individual interests residing in the public domain.

Meanwhile, in Romm Art the court additionally found that the trade dress in question was nonfunctional, despite the fact that it involved "an aesthetic work of art."142 Applying the holding of a Tenth Circuit case involving greeting cards, ${ }^{143}$ the court in Romm Art appeared to find that "the overall appearance or look" of the plaintiff's works was not functional. ${ }^{144}$ The court quoted with approval a passage from the district court opinion in the Tenth Circuit case:

[O]ne salutary purpose of the Lanham Act in this context is to protect a creative artist's rights in his or her creation and thus provide an incentive to be creative. By protecting and fostering creativity, a product with features different and perhaps preferable ... may well be developed. Offering consumers a choice . . . stimulates, rather than stifles competition. ${ }^{145}$

Confronted, then, by a defense of what amounted to aesthetic functionality, the court in Romm Art reached naturally enough for the language of copyright and the Intellectual Property Clause in justifying the injunctive relief it proposed to give. But under analysis standard to trade dress, none of the prerequisites, the safeguards, the precautions - the more than two centuries of carefully tested doctrines to be found in copyright-were reflected in the judgment arrived at by the court. Nor does the court's opinion imply any recognition of the public domain.

140. Id at 1140 . The works by Tarkay were priced between $\$ 230$ and $\$ 700$, while the work by Patricia sold for an average price of $\$ 30$.

141. See id. at 1139 (quoting Charles of the Ritz Group v. Quality King Dist., 832 F.2d 1317, 1322 (2d. Cir. 1987)).

142. See id. at 1134-35.

143. Hartford House v. Hallmark Cards, Inc., 647 F.Supp. 1533 (D.Colo. 1986), aff'd, 846 F.2d 1268 (10th Cir.), cert. denied, 488 U.S. 908 (1988).

144. See Romm Art, 786 F. Supp. at 1135 ("In light of the foregoing, the Court concurs in and adopts the finding of the Magistrate Judge that the Tarkay posters and limited editions are [nonfunctional and therefore] entitled to protection under $\$ 1125(a)$ of the Lanham Act.").

145. Id. (citing Hartford House, 647 F. Supp. at 1540). 
Which is why it matters, if trade dress law is to be extended to cases like these, that we pay close attention to what Pollack and Davis (and others who have addressed these issues before them) have suggested about the pertinence of the Intellectual Property Clause.

Their broader analysis allows us to bring the Clause to bear directly in Romm Art, Lanham Act or no; Pollack's analysis of direct preemption allows us to bring the Clause to bear against state law as well. Davis's analysis, meanwhile, reminds us that trade dress cases must always be tested, when the Clause applies, against the requirements of the public domain and the individual's right to copy. The presumption that an intent to copy is equivalent to an intent to cause confusion cannot survive analysis under this construction of the Intellectual Property Clause. Were it otherwise, then any exercise of public domain rights resulting in appropriation with respect to competing works might easily translate into an all-but-automatic trademark infringement. Surely the public domain is not so fragile.

Similarly, the concepts of nonfunctionality and aesthetic functionality cannot have the traditional analysis they received in Romm Art. Whether functional or not from the point of view of established trade dress doctrine, the work in that case plainly deserved to be considered in terms of whether it did or did not embody the kind of originality protected by the Clause. In either case, all the limitations and restrictions imposed by the Clause would follow. On that ground, Romm Art was improperly decided as well.

Does this mean that no Lanham Act trade dress case like Romm Art can survive under the Intellectual Property Clause? Not necessarily. An earnest consideration of the Intellectual Property Clause does not mean that the Lanham Act is no longer alive and well. It means merely that accommodations must be made between the important work that Act was designed to do and the new realities that flow from merging doctrines in the intellectual property field. The Lanham Act will continue to authorize appropriate relief against confusion, deception, misrepresentation, false advertising, and the like when those threats are real. These are the traditional concerns of trademark and unfair competition law, and nothing in the Intellectual Property Clause forbids suitably limited relief against these consequences or practices when they are demonstrated with substantial particularity. ${ }^{146}$

146. See Gleiberman, supra note 30 , at $2050-55,2065-70$. It is plausible, I think, to imagine that proof with particularity will become central to any newly emerging constitutional jurisprudence, just as has been the case under the First Amendment's impact on the field of defamation. See New York Times Co. v. Sullivan, 376 U.S. 254, 283-84 (1964).

While Alabama law apparently requires proof of actual malice for an award of punitive damages, where general damages are concerned malice is "presumed." Such a presumption is inconsistent with the federal rule .... Since the trial judge did not instruct the jury to differentiate between general and punitive damages, it may be that the verdict was wholly an award of one or the other. But it is impossible to know, in view of the general verdict returned.

Id. Cf. Gertz v. Welch, 418 U.S. 323,349 (1974) ("Under the traditional rules pertaining to actions for libel, the existence of injury is presumed from the fact of publication. Juries may award substantial 
Presumptions derived from the mere fact of copying itself, however, cannot withstand scrutiny except as dictated by the Clause. More to the point, assumptions derived from concepts of functionality or nonfunctionality cannot be indulged without additional inquiry to see how and whether they actually measure up to the heightened standards imposed by the Clause in the circumstances peculiar to a given case. ${ }^{147}$ Similarly, it may be necessary to tailor Lanham Act remedies anew. Courts very properly have recognized the dubious propriety of injunctive relief against copying when other forms of relief would suffice in cases affected by the Clause. ${ }^{148}$ Now the Lanham Act may be subject to this limitation as well.

\section{IV}

In two quite distinct, but complementary works, Professors Pollack and Davis have offered valuable analysis leading toward a comprehensive theory of constitutional constraint in the field of trademark law. Each of them has demonstrated that Congress may not escape the strictures of the Intellectual Property Clause by turning to the Commerce Clause. Professor Pollack has shown how the Intellectual Property Clause can apply directly to the states as well as to Congress. Professor Davis has shown how a constitutionally derived right to copy, drawn from Feist and the cases that shaped it, may lead to more effective recognition of the public domain.

Of course much additional thought will need to be given to this subject before widespread consensus can be hoped for, much less achieved. It is both appropriate and timely to work toward that end as we celebrate the fiftieth anniversary of the Lanham Act.

\footnotetext{
sums as compensation for supposed damage to reputation without any proof that such harm occurred. The largely uncontrolled discretion of juries to award damages where there is no loss unnecessarily compounds the potential of any system of liability for defamatory falsehood to inhibit the vigorous exercise of First Amendment freedoms.").

147. See supra note 108.

148. Honorable James L. Oakes, Copyrights and Copyremedies: Unfair Use and Injunctions, 18 HOFSTRA L. REV. 983, 996 (1990) ("Injunctive relief should remain a matter of informed discretion in the law of copyright infringement as it does in the law of nuisance, riparian rights, trespass, or other torts.").

In order to accommodate the universal interests served by the law of intellectual property, as well as do justice or equity in the individual case, we must for a while, until better advised, look to the remedy rather than merely to the substantive rule of law, or at least to the relationship between the two, to see that the law continues to grow commensurate with the times rather than recedes into the past.

Id. at 1003.
} 